УДК 336.71

JEL: E22, M21

\title{
Савченко М.В.
}

д.е.н., доцент, завідувач кафедри міжнародних економічних відносин, Донецький національний університет імені Василя Стуса

ORCID: 0000-0002-9063-3551

m_savchenko@donnu.edu.ua

\section{Слободян Р.O.}

Голова Державної інспекції енергетичного нагляду України

ORCID: 0000-0001-6355-2337

ruslan.slobodyan@gmail.com

\section{КОНЦЕПТУАЛЬНІ ОСНОВИ УПРАВЛІННЯ ІНВЕСТИЦІЙНОЮ ДІЯЛЬНІСТЮ ЕЛЕКТРОЕНЕРГЕТИЧНОГО ПІДПРИЄМСТВА}

У статті визначено особливості підприємств електроенергетики як учасників інвестиційного процесу, щзо враховані при розробці концептуальних положень управління процесом інвестування підприємства електроенергетики. Досліджено зміст дефініції «управління інвестиційною діяльністю підприємства». Визначено етапи управління інвестиційною діяльності підприємства, серед яких: аналіз інвестиційного клімату країни; інвестииійна діагностика; визначення обсягу інвестиційних ресурсів; розробку, вибір $і$ реалізацію заходів з досягнення певного стану інвестиційної привабливості; інтенсифікація припливу інвестицій в об'єкти інвестування; зміна стану підприємства за рахунок ефекту від інвестування.

Обгрунтовано, щуо ефективні інвестищійні рімення на мікрорівні можуть привести до підвищення, вартості підприємства. 3 врахуванням особливостей інвестиційної діяльності на рівні підприємств електроенергетики визначено принципи управління.

Запропонована модель підвищення ефективності інвестиційної діяльності підприємства за критерієм максимізацій його вартості.

Ключові слова: електроенергетика, інвестииї, інвестиційна діяльність, інвестищійна діагностика, принципи забезпечення, інновачійний прочес, управління інвестиційною діяльністю, підприємство.

Рис. - 3, Літ. -13.

Постановка проблеми. Електроенергетика - одна 3 найважливіших галузей національної економіки України, на їі частку припадає в середньому 3\% ВВП країни [1]. В сучасному суспільстві без використання електроенергії практично неможливо уявити нормальне функціонування різного роду установ, організацій, побутового сектора, а виробничий процес сільськогосподарських та промислових підприємств і зовсім повністю паралізується [2].

Основним фактором, що стримує розвиток електроенергетичної галузі України, $є$ значний зношення електрообладнання. Сьогодні рівень фізичного зношення виробничих активів в електроенергетиці досяг в середньому 60-70\%. Так, наприклад, найменш 
зношені виробничі активи єдиної національної (магістральної) електричної мережі (50\%), наступним за ступенем зношеності є обладнання генерації електроенергії (60$65 \%$ ). Найбільш зношені виробничі активи знаходяться в розподільному електромережевому комплексі - зношення в середньому понад 70\%. Враховуючи, що найбільш інтенсивне будівництво основних фондів електроенергетики приходилося на 60-70 роки минулого століття, то стає цілком очевидним той факт, що знос експлуатованого електрообладнання вже переступив свій критичний рівень [3]. Отже, підприємства електроенергетичної галузі потребують значних обсягів капіталовкладень для оновлення та модернізації своїх виробничих потужностей. Проте для інвесторів вони залишаються непривабливими через певні наявні особливості їх діяльності.

Аналіз останніх досліджень та публікацій. Дослідженню питань управління інвестиційною діяльністю підприємства приділяли увагу іноземні і вітчизняні науковці: Н. Бондар, А. Загородній, О. Заєць, Н. Замятіна, П. Кухта, В. Левицький, Г. Марковіц, О. Терещенко, Д. Тобін, А. Череп, В. Шарп, В. Шевчук. Проте, подальшого дослідження потребують питання, пов'язані з управлінням інвестиційною діяльністю підприємств України.

Метою дослідження $\epsilon$ формування концептуальних основ управління інвестиційною діяльністю електроенергетичних підприємств України.

Викладення основного матеріалу. Специфіка електроенергетики як об'єкта інвестування обумовлена необхідністю виконання нею соціальних та інфраструктурних функцій, а також через іiї значущість в забезпеченні національної безпеки країни взагалі. Саме тому підприємства електроенергетичної галузі можна назвати «особливими учасниками» інвестиційного ринку, а їх інвестиційній діяльності, коли підприємство виступає і як об’єкт, і (або) як суб'єкт інвестування, притаманні певні відмітні риси (рис. $1)$.

\section{О С О Б Л И В О С Т І}

1 Діяльність підприємств електроенергетики не може бути спрямована лише на отримання прибутку

2 Підприємства енерговиробничих галузей є природними монополіями зі значним державним впливом на їх діяльність

3 Фінансова, організаційна та технічна складність реалізації інвестиційних проєктів в електроенергетиці

4 Електроенергетика є стратегічною галуззю зі значним безпосереднім впливом на безпеку держави, що обмежує вільну участь зарубіжних інвесторів в інвестиційних проєктах з електроенергетики

5 Динамічність тарифів на електроенергію ускладнює прогнозування виручки і планування повернення інвестованих коштів

6 Початкова стадія впровадження ринкових засад в електроенергетиці, адаптація підприємств галузі до інвестиційної діяльності за новими правилами

Рисунок 1. Особливості підприємств електроенергетики як учасників інвестиційного процесу

Джерело: побудовано авторами самостійно 
Більшість практиків та вчених вважають, що лібералізація ринку електроенергетики пожвавить інвестиційні процеси та створить сприятливий інвестиційний клімат в галузі ринка [4]. Проте існує протилежна думка 3 посиланням на зарубіжний досвід, що лібералізація енергетичної галузі обумовить ризик дефіциту інвестицій в їі розвиток $[5$, с. 91; 6]. Раціональність цієї думки полягає в тому, що лібералізація усунить державу 3 масштабних інвесторів для електроенергетики, а особливості інвестиційних процесів в галузі не приваблять сторонніх інвесторів зовні, i тоді інвестувати в розвиток підприємства будуть лише за рахунок власних джерел. Слушність цього доводу можна будить оцінити з часом.

Проте слід зазначити, що брак інвестиційних ресурсів стосується не тільки електроенергетичної галузі. Це проблема стала макроекономічною для України в цілому. Дуже складно привабити інвесторів в економіку, в якій розмір щорічного відтоку капіталу становить 12-18 млрд дол., і це лише вершина айсберга. Цю проблему потрібно вирішувати на державному рівні.

Таким чином, перераховані вище відмітні риси електроенергетики як сфери інвестування призводять до того, що капіталовкладення повинні носити досить довгостроковий характер (не менше 10 років), при цьому інвестор має бути готовим до більш низької норми доходу, в порівнянні з середньоринковою, і не має права формувати тариф на електроенергію на свій розсуд з метою якнайшвидшого повернення своїх вкладень. Це знижує інвестиційну привабливість енергетичної галузі.

Розглянуті особливості інвестиційної діяльності підприємств електроенергетичної галузі повинні бути враховані при розробці концептуальних положень управління процесом інвестування підприємства електроенергетики.

Управління інвестиційною діяльністю - це складова частина загальноекономічної системи управління підприємством, яка має свою мету, принципи та методи розробки та реалізації управлінських рішень, пов'язаних із здійсненням різних аспектів інвестиційної діяльності [7, с. 41].

Досліджуючи зміст дефініції «управління інвестиційною діяльністю підприємства» доцільно 3 початку з'ясувати етимологію поняття «управління». Згідно із тлумачним словником, управляти - означає «спрямовувати хід якогось процесу, впливати на розвиток, стан будь-чого» [8, с. 469]. Відповідно, в найпростішому трактуванні управління інвестиційною діяльністю підприємства $\epsilon$ цілеспрямованим впливом певних суб'єктів на стан та розвиток інвестиційної діяльності, хід інвестиційного процесу. Крім того, управлінській діяльності притаманні й інші аспекти:

- «перетворення інформації про стан об’єкта в командну інформацію від суб’єкта» [46];

- «цілеспрямований програмований чи довільний вплив на об'єкти задля досягнення кінцевої мети за допомогою явищ, процесів...» [9];

- «функція системи, спрямована на виживання цієї системи за допомогою координації, організації, впорядкування елементів даної системи як між собою (всередині себе), так і з зовнішнім середовищем» [10];

- «діяльність суб'єкта, спрямована на зміну стану об'єктів і (або) суб'єктів (у тому числі і себе), за заздалегідь продуманим планом дій» [10];

- «діяльність 3 приведення об'єктивного процесу до суб'єктивно обраної мети»;

- «це елемент функціонування організаційних систем (біологічних, технічних, соціально-економічних тощо)» [9].

Управління інвестиційною діяльністю підприємства $\epsilon$ складним, багаторівневим процесом, що передбачає розробку та прийняття управлінських рішень як на мікрорівні безпосереднім учасником інвестиційної діяльності - підприємством, так і на макро- і мезорівнях. 
Зазначимо, що метою управління на макро- та мезорівнях є створення сприятливих умов здійснення інвестиційної діяльності суб'єктами господарської діяльності на певній території, тоді як на мікрорівні управлінські рішення спрямовані на максимізацію ефективності інвестиційної діяльності окремого підприємства.

Процес управління інвестиційною діяльності підприємства включає певні етапи:

Перший етап управління інвестиціями на рівні підприємства - це аналіз інвестиційного клімату країни.

На другому emani процесу управління інвестиційною діяльністю підприємства необхідно оцінити інвестиційний стан суб'єкта господарювання за допомогою проведення інвестиційної діагностики. Як показує практика для економічного обгрунтування інвестиційних вкладень недостатньо використовувати лише стандартні методи оцінки економічної ефективності інвестиційних проектів, які наведені у відповідних методичних рекомендаціях, або проаналізувати фінансовий стан підприємства - об'єкта вкладення. У цьому випадку необхідно провести саме інвестиційну діагностику.

Інвестиційна діагностика - це поняття більш широке, що характеризує не тільки даний стан справ в інвестиційній сфері підприємства, а й визначає майбутні перспективи розвитку на основі оцінки інвестиційного потенціалу та інвестиційної привабливості.

Взаємозв'язок інвестиційної та фінансової діагностики представлений на рис. 2.

Ha третьому етапі доцільно визначити необхідний обсяг інвестиційних ресурсів і значення показника інвестиційної привабливості, до якого слід прагнути для залучення позначеного обсягу інвестицій.

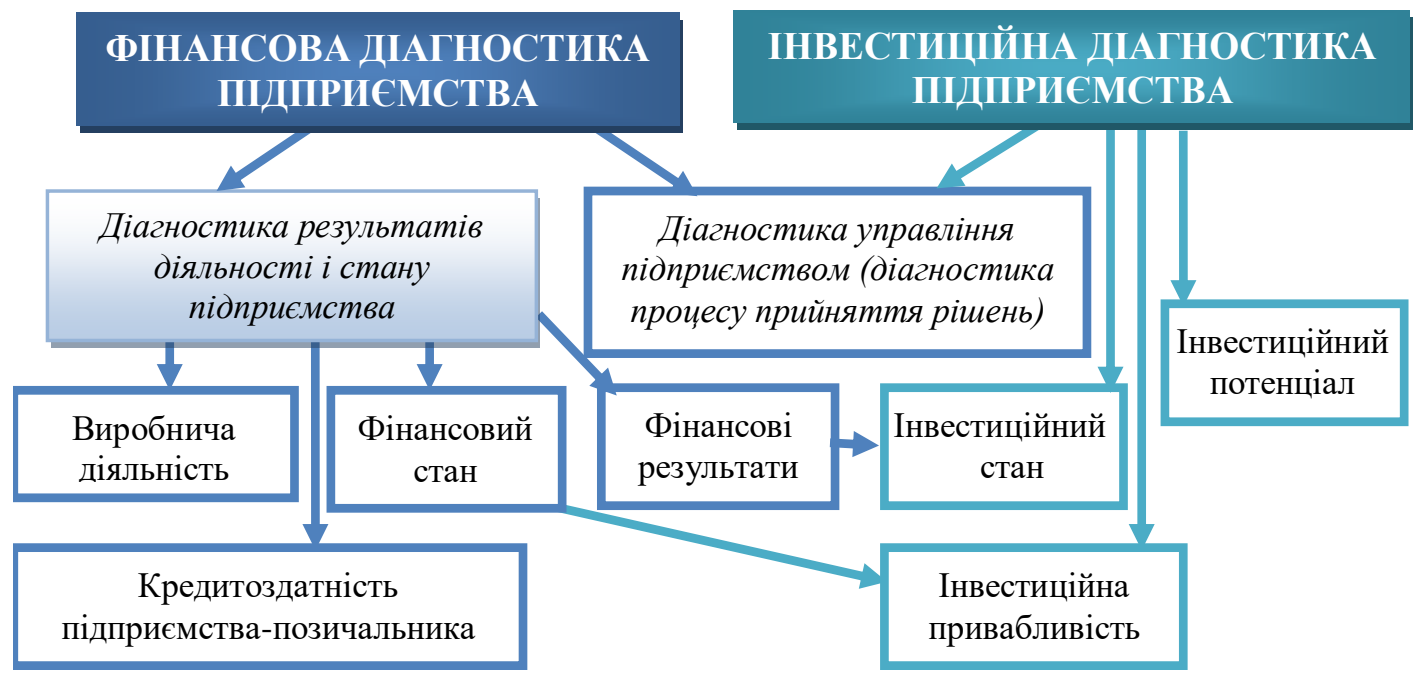

Рисунок 2. Взаємозв’язок фінансової та інвестиційної діагностики Джерело: побудовано авторами на основі [11]

В електроенергетиці найбільш значущими джерелами інвестиційного фінансування виступають: тарифне джерело; власні кошти (прибуток) підприємства; позикові кошти; залучені засоби [12].

Четвертий етап передбачає розробку, вибір і реалізацію заходів, що дозволяють отримати необхідний стан інвестиційної привабливості системи управління інвестиційною діяльністю підприємства. Процес управління інвестиційною діяльністю підприємства повинний базуватися на регулюванні інвестиційної привабливості економічного суб'єкта (оскільки інвестиційна привабливість обумовлює приплив (відтік) капіталу). 
3 огляду на особливості інвестиційної діяльності на рівні підприємств електроенергетики, управління інвестиційною діяльністю має базуватися на таких принципах: континуальність, комплексність, єдність пріоритетів інвестиційної політики, відповідність інвестииійної стратегї довгостроковим і поточним иілям функиіонування підприємства, відповідність інвестиційної діяльності підприємства його фінансовим і інвестиційним ресурсам, оптимізація співвідномення прибутковості $i$ ризику, прибутковості $i$ ліквідності, забезпечення керованості інвестиційним портфелем.

Ефективна реалізація перших трьох етапів визначає рівень n'ятого emany, який характеризується зміною (інтенсифікацією) припливу інвестицій в об'єкти інвестування, що обумовлено, в свою чергу, зміною інвестиційної привабливості. В даному контексті необхідно враховувати, що інвестиційний процес протікає спіралеобразно і складається 3 «замкнутих» ланцюжків (циклів): від суб'єкта управління до суб'єкта управління, але вже якісно нового рівня [13, с. 162].

Отже, шостий етап процесу управління інвестиційною діяльністю підприємства $€$ результативним і включає в себе зміни інвестиційного і фінансового стану суб'єкта господарювання за рахунок ефекту від інвестування, що полягає в зміні темпів економічного зростання.

Запорукою успішної інвестиційної діяльності $є$ забезпечення високої якості прийнятих інвестиційних рішень. Результати інвестиційної діяльності визначають і перспективи розвитку підприємства в цілому, оскільки реалізація інвестиційних проектів може привести як до підвищення, так і до зниження вартості підприємства.

Отже, механізм управління інвестиціями підприємства, побудований через моделювання інвестиційних потоків, має основуватися на виявленні чинників та умов максимізації вартості підприємства.

На підставі моделі «входів-виходів» визначимо складові моделі підвищення ефективності інвестиційної діяльності підприємства на основі максимізації його вартості (рис. 3).

Висновки. Таким чином, модель підвищення ефективності інвестиційної діяльності підприємства на основі максимізації його вартості, що відображає вплив результатів інвестицій на зміну вартості підприємства і що дозволяє, по-перше, оцінити ефективність інвестиційних рішень, по-друге, визначити вплив інвестиційних потоків на фінансовий стан підприємства, i, по-третє, відобразити зміну конкурентних переваг i ринкових позицій підприємства.

Отже, безперервна реалізація процесу управління інвестиційною діяльністю підприємства (відповідно до зазначених етапів) обумовлює удосконалення системи управління інвестиційною діяльністю підприємства, підвищує ефективність його функціонування і в результаті сприяє економічному зростанню підприємства. 


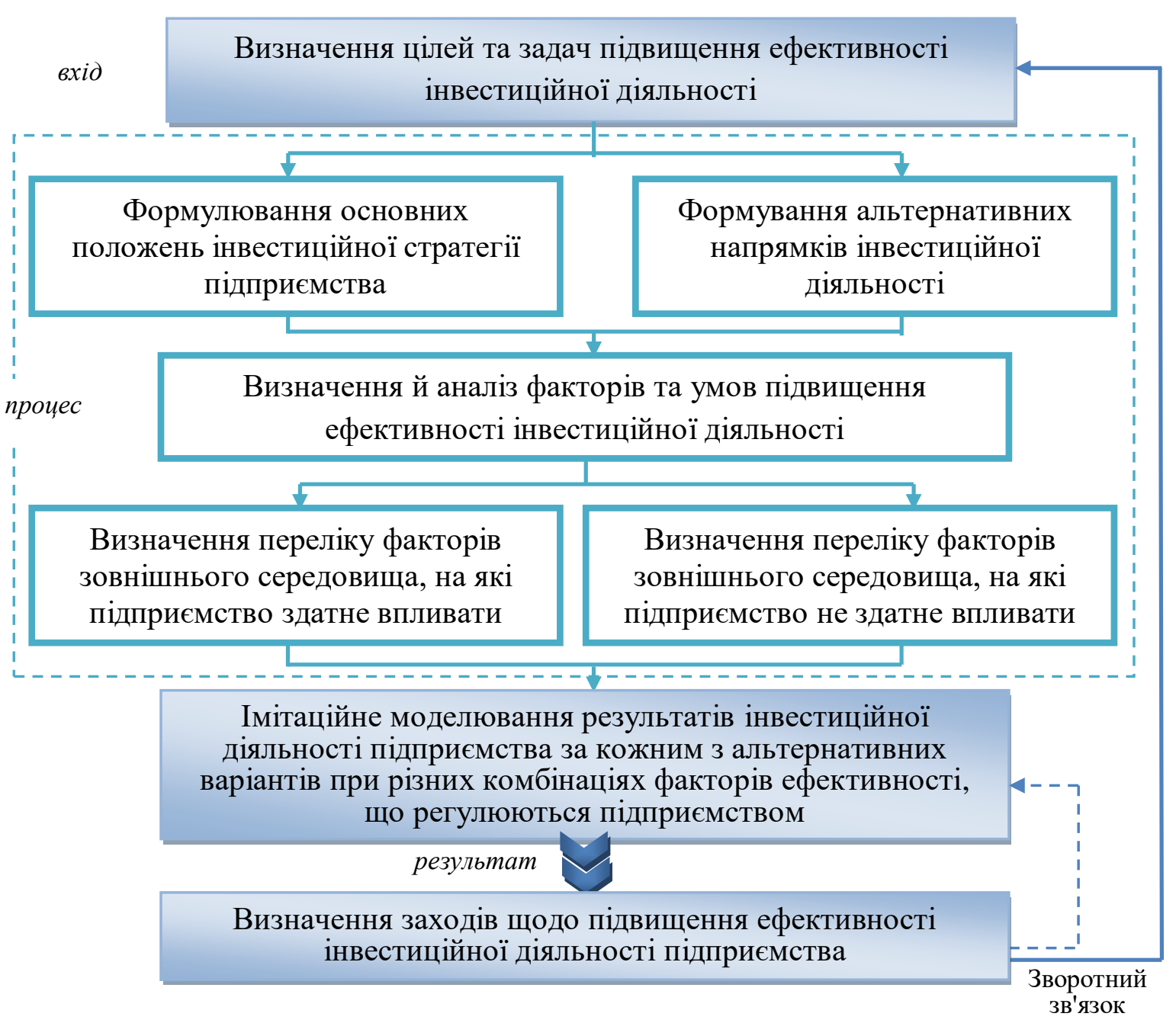

Рисунок 3. Модель підвищення ефективності інвестиційної діяльності підприємства на основі максимізації його вартості

Джерело: побудовано авторами самостійно

\section{СПИСОК ВИКОРИСТАНИХ ДЖЕРЕЛ}

1. Державна служба статистики України. URL: http://www.ukrstat.gov.ua.

2. Боярков Д.А. Управление производственными активами электросетевых компаний на основе риск-ориентированного подхода. Современный специалистпрофессионал: теория и практика. Материалы XI Международной научной конференции студентов и магистрантов в рамках $\mathrm{X}$ Международного научного студенческого конгресса «Образ будущего глазами студентов» / под общей редакцией В.А. Ивановой, Т.Е. Фасенко. Барнаул: Графикс, 2019. С. 13-16.

3. Старкова Н.О., Зубко Д.В. Основные проблемы развития и инвестирования российской электроэнергетики. Бюллетень науки и практики. 2016. №. 11. С. 170-176.

4. Палійчук У.Ю. Передумови та засади лібералізації ринку електроенергії в контексті євроінтеграційних намірів України. Науковий вісник ІФНТУНГ. Серія: Економіка та управління в нафтовій і газовій промисловості. 2016. № 1(13). С. 97-107.

5. Баскова А.Р. Инвестиции в основной капитал єлектроєнергетики как фактор роста и инноваций. Вестник АГТУ. Серия: Экономика. 2012. № 1. С. 91-96. 
6. Зеленюк Т.А. Систематизація світового досвіду лібералізації ринку електроенергії. Науковий вісник Херсонського державного університету. 2014. Вип. 6(1). C. 195-198. URL: http://nbuv.gov.ua/UJRN/Nvkhdu_en_2014_6\%281\%29_49.

7. Майорова Т. В. Інвестиційна діяльність: підручник. К.: Центр учбової літератури, 2009. $472 \mathrm{c}$.

8. Словник української мови: в 11 томах. Том 10, 1979.

9. Управління. Вікіпедія. URL:http://uk.wikipedia.org/wiki/Управління.

10. Халиков М. И. Система государственного и муниципального управления: учеб. пособ. М.: Флинта, 2008. 448 с.

11. Бородкин К.В., Преображенский Б.Г. Анализ инструментария финансовой диагностики. Финансы. 2004. № 3.

12. Лехнер А.А. Особенности реализации инвестиционной деятельности электросетевых компаний. Современный специалист-профессионал: теория и практика Материалы XI Международной научной конференции студентов и магистрантов в рамках X Международного научного студенческого конгресса «Образ будущего глазами студентов» / под общей редакцией В.А. Ивановой, Т.Е. Фасенко. Барнаул: Графикс, 2019. C. $130-133$.

13. Валинурова Л. С. Управление инвестиционной деятельностью: учебник. М.: КНОРУС. 2005. 384 c.

\section{REFERENCES}

1. Derzhavna sluzhba statystyky Ukrainy. URL: http://www.ukrstat.gov.ua.

2. Boyarkov, D.A. (2019) Upravlenie proizvodstvennyimi aktivami elektrosetevyih kompaniy na osnove risk-orientirovannogo podhoda [The main problems of development and investment of the Russian electric power industry]. Sovremennyiy spetsialist-professional: teoriya i praktika. Materialyi XI Mezhdunarodnoy nauchnoy konferentsii studentov i magistrantov v ramkah X Mezhdunarodnogo nauchnogo studencheskogo kongressa «Obraz buduschego glazami studentov» / pod obschey redaktsiey V.A. Ivanovoy, T.E. Fasenko. Barnaul: Grafiks, 2019. pp. 13-16. (in Russian).

3. Starkova, N.O., Zubko, D.V. (2016) Osnovnyie problemyi razvitiya i investirovaniya rossiyskoy elektroenergetiki [The main problems of development and investment of the Russian electric power industry]. Byulleten nauki i praktiki. 2016. no. 11. pp. 170-176.

4. Paliichuk, U.Iu. (2016) Peredumovy ta zasady liberalizatsii rynku elektroenerhii v konteksti yevrointehratsiinykh namiriv Ukrainy [Preconditions and principles of liberalization of the electricity market in the context of Ukraine's European integration intentions]. Naukovyi visnyk IFNTUNH. Seriia: Ekonomika ta upravlinnia v naftovii i hazovii promyslovosti. no. 1(13). pp. 97-107.

5. Baskova, A.R. (2012) Investitsii v osnovnoy kapital ElektroEnergetiki kak faktor rosta $\mathrm{i}$ innovatsiy [Investment in fixed assets of the power industry as a factor of growth and innovatio]. Vestnik AGTU. Seriya: Ekonomika. no. 1. pp. 91-96.

6. Zeleniuk, T.A. (2014) Systematyzatsiia svitovoho dosvidu liberalizatsii rynku elektroenerhii [Systematization of world experience in electricity market liberalization]. Naukovyi visnyk Khersonskoho derzhavnoho universytetu. Vyp. 6(1). pp. 195-198. URL: http://nbuv.gov.ua/UJRN/Nvkhdu_en_2014_6\%281\%29_49.

7. Maiorova, T. V. (2009) Investytsiina diialnist [Investment activity]. K.: Tsentr uchbovoi literatury. 472 p. (in Ukrainian).

8. Slovnyk ukrainskoi movy: v 11 tomakh. Tom 10, 1979. (in Ukrainian). 
9

Upravlinnia

[Management].

Vikipediia.

URL:http://uk.wikipedia.org/wiki/Upravlinnia.

10. Halikov, M. I. (2008) Sistema gosudarstvennogo i mu $\neg$ nitsipalnogo upravleniya [System of state and municipal government]. M.: Flinta. 448 p. (in Russian).

11. Borodkin, K.V., Preobrazhenskiy, B.G. (2004) Analiz instrumentariya finansovoy diagnostiki [Investment in fixed assets of the power industry as a factor of growth and innovatio]. Finansyi. no. 3.

12. Lehner, A.A. (2019) Osobennosti realizatsii investitsionnoy deyatelnosti elektrosetevyih kompaniy [Features of the implementation of investment activities of power grid companies]. Sovremennyiy spetsialist-professional: teoriya i praktika Materialyi XI Mezhdunarodnoy nauchnoy konferentsii studentov i magistrantov $v$ ramkah $X$ Mezhdunarodnogo nauchnogo studencheskogo kongressa «Obraz buduschego glazami studentov» / pod obschey redaktsiey V.A. Ivanovoy, T.E. Fasenko. Barnaul: Grafiks. pp. 130133. (in Russian).

13. Valinurova, L. S. (2005) Upravlenie investitsionnoy deyatelnostyu [Management of investment activity]. M.: KNORUS. 384 p. (in Russian).

\section{Савченко М.В., Слободян Р.О. КОНЦЕПТУАЛЬНЫЕ ОСНОВЫ УПРАВЛЕНИЯ ИНВЕСТИЦИОННОЙ ДЕЯТЕЛЬНОСТЬЮ ЭЛЕКТРОЭНЕРГЕТИЧЕСКОГО ПРЕДПРИЯТИЯ}

В статье определены особенности предприятий электроэнергетики как участников инвестиционного процесса, которые учтень при разработке концептуальных положений управления прочессом инвестирования предприятия электроэнергетики. Исследовано содержание дефиниции «управление инвестищионной деятельностью предприятия». Определень этапь управления инвестиционной деятельности предприятия, среди которых: анализ инвестиционного климата страны; инвестииионная диагностика; определение объема инвестииионных ресурсов; разработка, выбор и реализация мероприятий по достижению определенного состояния инвестиционной привлекательности; интенсификация притока инвестиций в объекты инвестирования; изменение состояния предприятия за счет эффекта от инвестирования. Обосновано, что эффективные инвестиционные решения на микроуровне могут привести к повышению стоимости предприятия. С учетом особенностей инвестиционной деятельности на уровне предприятий электроэнергетики определены принциипы управления. Предложена модель повышения эффективности инвестищионной деятельности предприятия за критерием максимизации его стоимости.

Ключевье слова: электроэнергетика, инвестиции, инвестиционная деятельность, инвестиционная диагностика, принципы, инновачионное процесс, управление инвестиционной деятельностью, предприятие.

\section{Savchenko, R. Slobodian CONCEPTUAL BASES FOR MANAGING THE INVESTMENT ACTIVITY OF AN ELECTRIC POWER ENTERPRISE}

The article identifies the features of electric power enterprises as participants in the investment process, which are taken into account when developing conceptual provisions for managing the investment process of an electric power enterprise. The content of the definition «management of the investment activity of an enterprise» has been investigated. The stages of management of the investment activity of the enterprise are determined, including: analysis of 
the investment climate of the country; investment diagnostics; determination of the volume of investment resources; development, selection and implementation of measures to achieve a certain state of investment attractiveness; intensification of the inflow of investments into investment objects; change in the state of the enterprise due to the effect of investment. It has been substantiated that effective investment decisions at the micro level can lead to an increase in the value of an enterprise. Taking into account the specifics of investment activities at the level of electric power industry enterprises, management principles have been determined. A model for increasing the efficiency of the investment activity of an enterprise is proposed based on the criterion of maximizing its value.

Key words: electric power industry, investments, investment activity, investment diagnostics, principles, innovation process, investment management, enterprise. 